Supplement of Nat. Hazards Earth Syst. Sci., 17, 157-170, 2017

http://www.nat-hazards-earth-syst-sci.net/17/157/2017/

doi:10.5194/nhess-17-157-2017-supplement

(C) Author(s) 2017. CC Attribution 3.0 License.

(c) (1)

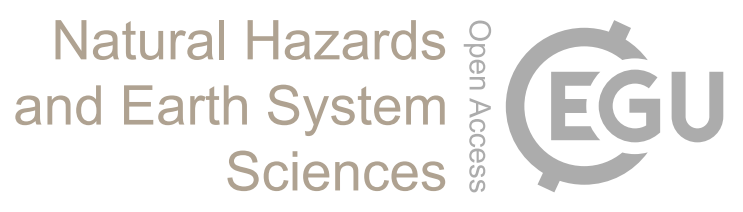

Supplement of

\title{
A reconstruction of 1 August 1674 thunderstorms over the Low Countries
}

\section{Gerard van der Schrier and Rob Groenland}

Correspondence to: Gerard van der Schrier (schrier@knmi.nl)

The copyright of individual parts of the supplement might differ from the CC-BY 3.0 licence. 


\title{
Supplementary Information
}

\author{
transcription of Gerrit Jansz. Kooch's rhyme in English
}

\section{Hollans Orkaen}

ofte verhael van de ongemeend ende noyt diergelijcke stormwint hier te lande gesien nergens de schade van de verschrickelijcke donder geschiet den eerste augusti 1674 op een beede dach

1 ge hebt in 't voorgaende boeck gesien hoe dat men alsdoen sach geschien twee wonders waerdich te onthouwen maer dat hier nu vervolgen sal dat is noch wel het grootst van al en vreeselijck om te aenschouwen

$2 \quad$ ick tel nu 't seventich ses jaer ' $\mathrm{k}$ heb in mijn tijt door stormen swaer van donder blicksem hagel buyen in prijkel en in noot geweest maer wat men daer af schrijf of leest en heeft hier bij niet te beduijen

3 't gedenckt mijn hoe dat konstisch werk de glasen in de suijder kerck daer door de gilden in gegeven door groote hagelsteenen swaer aen deen sij van de kerck bijnaer naeu een en ruyt was heel gebleeve

4 't gedenckt mijn dat door stormen groot al op de korenbeurs het loot dat in de goote was geleegen was opgerolt met groote cracht al hadden tien man aen gewracht men hadt het soo net niet gekregen

$5 \quad$ noch gedenkt mijn een swaer tempeest dat dier gelijck oock is geweest dat was doen van de westertooren dat sware kruys aen stucken brack en viel al door het kerkcken dack dan heb ick u noch hier te voore

\section{Dutch Hurricane}

This is a story of a rare gale

which has in this country never been seen before the damage and the terrible thunder as occurred on the first of August on an evil day

In the previous book you have seen how it has happened, two miraculous events, worthy to remember but what now follows is the most awesome of all and terrible to see unfold.

I've reached seventy and six years now and I have been in many heavy gales full with thunder, lighting, hail and showers frightened and in despair but what is written or read about these storms they don't mean anything compared to this one

I'm thinking of the craftmanship of the stained windows of the suijder $\operatorname{church}^{1}$ made by the city's guilds destroyed by large and heavy hail on one side of the church hardly any window was saved

I'm thinking of the force of the great storm that the lead of the corn exchange in its gutters was coiled up by an enormous force even if 10 men had tried they wouldn't have succeeded

I can't remember a strong gale equally strong as this one that worked on the Westertoren and broke that heavy cross in many pieces which fell through the church's roof And then I have here for you

\footnotetext{
${ }^{1}$ Zuiderkerk
} 
6 in't bladt hier voor gewesen aen hoe dat de roon-poorts toorens haen de vlucht nam doorde wint gedreeve en dat dien felle wint het kruys van boven neer smeet op ons huys 't scheen dat het kosten sou ons leeve

$7 \quad$ veel harde winden nu en dan die ik hier niet noemen kan die veel schoorsteenen nederdruckte de daecken brack en woeij om veer de gevels smeet van boven neer en boomen uyt der aerde ruckte

8 hoe meenichten van scheepen mee in tessel 't vlie en hier voor stee sijn om gewaeyt en oock gesonken 't getal dat is te over groot van menschen die in sulken noot gesneuvelt sijn ende verdronke

$9 \quad$ veel wonders heb ick ook gesien dat door natuer niet con geschien maer door de schrickelijcke donder maer 't geen dat hier nu volgen sal dat is het wonderlijckst van al en speelde oock wat crachtichs onder

Want al die groote stormen swaer die nacht en dagen naer malkaer dack en schoorsteem deeden strijcken die sijn bij deze schade niet in een cort half uur geschiet in't minste deel niet te gelijcke

11 in augustus den eersten dach doe men dees donder vlaeg eerst sach die quamen ons eerst van uit het suijen van ${ }^{*}$ Brussel* $^{*}$ Mechelen* daer van daen maer 't geen ick van daer heb verstaen dat heeft soo veel niet te beduyen another tale to tell

how the cock of the Roopoort's towers

took to the air driven by the wind and that the fierce winds threw the cross down from above upon our house it appeared that we would die in the ordeal

many strong gusts now and then

that I can't enumerate here demolished many chimneys broke roofs and blew strong threw down many house's fronts and uprooted many trees

how numerous ships in Texel and the Vlie capsized due to winds en sunk the number is too large of the people that in great distress were killed or drowned

many miracles I have also seen which could not be done by nature but by the terrible thunder but what wil follow now is the most miraculous of all and very powerfull

Since all those strong gales continuous for nights and day breaking roofs and chimneys they are compared to this damage which was done in less than half an hour not the least comparable

in August the first day when this thunder gust was seen first which came from the south from Brussels and Mechelen but from what I have heard from there it did not impact too much

This tempest has also been in Antwerp but it hasn't been as strong as here in the evening between six and seven 
maer 't wasser mee al slecht gestelt die groote brugge over 't scheldt is door die wint mee wegh gedreven

13 daer was al mee veel schae geschiet maer hier bij te gelijcken niet gelijck de brieven dat vermelden schrijven van schoorsteen en van dack van groot gewoel en ongemack oock aen de scheepen op de schelde

tot ${ }^{*}$ santvliet* vier mijl daer van daen daer ginck het vreselijk aen daer alles voor die wint moest buijgen gelijck een molhoop lach die stadt kerck en huijsen alles plat glijck de brieven daer van tuijgen

te ${ }^{*}$ oudenbos* en *rosendael* al 't platte lant daer prinsepael dien swaeren donder heen passeerde molens en boomen om gewaeyt gebroocken en als afgedraeyt veel huysen oock ontramponeerde te ${ }^{*}$ turnhout* en daer omtrent bleef naeu een molen overent veel huysen lagen plat ter aerde ' $k$ heb de brieven van dat gewest selver gesien dies loof ick best dat sij de waerheijt oock verclaerde

tot Uttrecht was de schade groot daer bleven oock veel menschen doot van al de molens op de wallen soo sij ons schrijven daer vandaen er sijnde maer twee blyven staen de andre al te mael gevallen that large bridge over the Schelde river was affected badly

has floated away due to the winds

much damage has been done there but nothing compared to what happend here there are letters that tell of chimneys and roofs of great turmoil and discomfort also for the ships on the Schelde river

until Zandvliet four miles from there there a catastrophe occurred since everything had to give way to the winds the city became like a mole-hill church and houses all were destroyed testified by the letters

in Oudenbosch and Roosendaal in all of the countryside there where the heavy thunder passed windmills and trees upturned broken and twisted destroying many houses as well

In the neighborhood of Turnhout hardly any windmill was still standing many houses were lying on the ground I have the letters of that province seen myself and I believe that they are thruthfull

untill Utrecht the damage was extensive many people died there too of all the windmills on the city walls as they write us from there only two remained upright the others have all fallen

the face of the house Van der Haer is also destroyed, it's also true that many houses were severly damaged chmineys blown of houses scattered al over the streets to the extent that they could hardly be used 
19 de domkerck een gesticht seer out al met tiras seer hecht gebout drie hondert jaren hier te vooren is door des donders groot gewelt dat swaer verwelft ter neer gevelt van het coor af tot aen de tooren.

20 die sware brocken van de steen die vielen door de zerken heen en bleeuen in de graven steeken de kelder graven schoon hoe vast conden niet keeren desen last maer moesten door 't gewelt oock breeken

21 de dooden worden oock een deel gebrooken en verplettert heel noyt hadt ijemant daer af gedachten waer sal een mens dan sijn bewaert als men so diep noch onder d' aerdt al sulke rampen can verwachten

22 de pylaers seer dick ende swaer die men met dri man bij malkaer noch nauwelijcks omvamen konden die sijn vermorselt en verdraeijt en andre weer als afgemaeyt ses of acht voet boven de gronde

$\mathrm{Al}$ sulke zuijlen ses of acht daer 'e'en alleen wel hadt de macht om so een heel gebou te dragen dit worden daer soo metter vlucht daer nooyt geen mens voor was beducht gebrijselt en ter neer geslagen

24 een swaer pylaer een vaste schoor daer op rusten het hele koor was wel twee vaem geschuert en gekloven en onder hoe vast dat hij stont omtrent ses voeten van de gront al meerder als een duym verschooven

25 Sint Jakobs toren vil door 't dack die oock veel zerken [in] stucken brack the Dom church a building very old

with cement soundly build three hunderd years before is by the thunder's fierce violence downed that heavy building from the choir to the tower

the heavy lumps of stone fell through the tombstones and were stuck in the graves the graves in the church cellars, eventhough strongly build, couldn't withstand this force and broke because of this violence as well

the dead were also

broken and crushed completely never anybody had thought of that where can a man than find shelter if, even deep underground, one can expect such disasters

the pillars very tick and heavy which could hardly be embraced by tree men together, are crushed and twisted and others are chopped of six or eight feet above ground

all these pillars six or eight where only one had the might to carry the complete structure are in a blink of an eye which nobody had expected shatterd and thrown to the ground

a heavy pillar on a fixed support on which the entire choir rested grated and split over a length of 2 vaem ${ }^{2}$ the lower part stood firm but about six feet from the ground it was relocated more than an inch

St. Jakob's tower fell through the roof which broke also many graves 
de dooden in 't graf quam verdruckten de swaren klocken van metael die sijn op twee naer allemaal door deesen val gebrocken stucken

de buier kerck deelden oock niet mis die mee geheel onbruijckbaer is men heeft noeyt dier gelijck geweten door dien het dack een groot partij en oock de muren ten weerzij sijn overhoop daer in gesmeeten de duytse huyskerck 't meerendeel is ingestort en voor 't geheel vervult met den gevallen tooren is soo beset met puyn en steen dat men ten diensten van 't gemeen die niet gebruyken kan als vooren

twee toorens van Sint Jakobskerck een out gesticht een deftich werck sijn beyde op het dack gevallen 't dack ingestort al met gewelt alwaer daar die kerck nu is gestelt soo desolaet als een van allen

Sinter Claes kerck bleef niet vrij stonden twee toorens zij aan zij daer of den 'e'en is neer gesmeeten als oock den tooren van agniet maer wat schae daer door is geschiet heb ick tot noch toe niet geweten

30 de brouwerij al van De Booch raeckten bij naest onderst om hoogh de groote kaetsbaen neer geslagen daer bleef naeulijcks een huijs bevryt of raeckten dack of schoorsteen quyt die seer dick op de straten lagen

31 de boomen worden neer gedruckt verscheydene uit de gront geruckt hoe vast gewortelt dat ze stonden palmagiebaen en op de wal the dead in the graves were crushed by the heavy bells of metal these are, apart from two, all broken to pieces by the fall

the Buurt church had its share too it is now completely useless nobody has ever since anything like it the roof is now a large pile of rubble and the walls on either side are thrown in as well

The Duitse house church has collapsed for the largest part and is now completely filled with the fallen tower it is full with debris and stones that it is no longer suitable for the purposes it had served

Two towers of the Sint Jacobs church an old institute and and a profound building have both fallen on the roof the roof has violantly collapsed so that the church is now as desolate as all the others

Sint Nicolas' church was also not spared two towers in tandem one of those was destroyed similarly to the tower of Agniet ${ }^{3}$ but I have not been informed of what damage has been done there

the brewery of De Boogh nearly got completely upturned along the large fives-court hardly any house was untouched most lost roof or chimney many of which were lying on the streets

the trees were floored several were uprooted no matter how firmly rooted the Palmagiestreet and on the city wall

\footnotetext{
${ }^{3}$ Agnieten monastry
} 
en door de stadt een groot getal

geschuert gebrooken en geschonden

32

de faem die ginck vast over al

van dese wonderlijcke val

het maekten veel menschen genegen

die quamen om dit wonderstuck

te sien van dit groot ongeluck

naer Uttrecht van verscheyde weegen

33 buijten de witte vrouwen poort daer sijn veel menschen oock versmoort die in een herberg haer begaven om schuylen voor dit onweer groot het huijs viel neer veel bleeven doot en onder puyn en steen begraven

34 de schrijver die schrijft noch voor waer dat van vieren een wandelaer was uijt het midden weg genomen de drie die quamen weer in 't aerdt maer van de vierde seijt men dat heij noech niet weder was gecomen

verhaelt daer bij dan noch een feyt maer voecht daerbij dat is men seyt hoe dat de menschen met een wagen sijn opgenomen in 't geheel de paerden met toom en gareel quamen in stee de tijding dragen

36 de dorpen rontom buyten stee die deelden oock van 't onheyl mee veel toorens raeckten daer algaende van *Houten*, *Bunnik* en noch meer van *Jutphaas* vil van boven neer van *IJsselsteyn* bleef oock niet staende

van lemmers heb ick dit verstaen dat broeckhuysen quam rijden aen dier onweer oock niet cost ontvlieden maer smeet de wagen los om veer de menschen op het aertrijck neer 't was omtrent *seijst* dat dit geschiede ick vroegde broeckhuysen daerna and thoughout the city a large number torn, broken and damaged

talk spread to everywhere of this miraculous case which made many people inclined to come to the city from everywhere and see this miracle

and the huge misery in Utrecht

outside the Wittevrouwenpoort many people died who fled into a guesthouse to take shelter for this large thunder storm the house collapsed and many died buried under the debris and stones

a writer writes that certainly one of four walkers was taken away the other three came down on the Earth but of the fourth it is said that he still is not found

I will tell you of another fact but add that this is said how that people with a wagon are taken up into the air the horses with bridle and horsecollar came to town to bring the message

the villages outside the city had their share of misery many towers got damaged of Houten, Bunnik and even Jutphaas fell down IJsselstein's tower didn't stay upright either

from Lemmers I heard

that Broekhuysen came riding into town he could not flee the thunder either which threw the wagon on its side and the people in it on the Earth's surface it was near Zeist that this happened

I asked Broekhuysen afterwards 
of 't soo geschied was hij seij ja sij met haer drijen quamen rijden met wagen paerden algelijck van de wech af tegen den dijck gesmeeten waren heel terseijden

de wagen vloogh aen stucken neer sij bleeven ook niet lang bijeen maer door dien fellen buij gedreven den eenen hier den ander daer wel twintich voeden van malkaer sij dachten daer te laten 't leven

want vielen sulke steenen groot en sij geheel van dack ontbloot en konde niewers onder schuylen en door de hagelsteenen swaer so was hun lichaem hier en daer oock hooft en handen vol van buylen

41 noch heeft mijn broeckhuysen vertelt dat daer omtrent was een groot velt dat men nou oversienen konden dat stont eerst schoon vol van bockweijt dat lach nu heel als afgemayt en neer geslagen tot den gronde

en noch een klucht dat was heel mooij een huysman op lant bij sijn hooy dat daer op hoopen was gedragen wiert opgenomen eer hij 't dacht geworpen in een droogen gracht soo lang als duerden deese vlagen

terwijl de wint het hooy ter vlucht als pluymen dreef tot in de lucht doen d'huysman weer quam tot bedaren die was bedwelmt in sijn verstant hij kende niet sijn aeijgen lant om datter geen hooy hoopen waren

hij dacht dit schijnt hier wel een spook ben ick in slaap of droom ick oock 't en is hier niet als van te vooren men sie hier geen hooy op het lant daer staen geen boomen op de kant if this was true, and he said yes all three were riding with wagon and horses and from the road they were thrown sideways against the dike

the wagon was smitten to pieces and the people could not stick together driven by the furious winds one here and the other there over twenty feet separated they thought they would die

such large stones fell from the sky and those without a roof over their heads could not find shelter and because of the weight of the hail stones their bodies, head and hands covered with bruises

Broekhuysen told me also that there was a large field in the vicinity so large that it could hardly be surveyed initially it was full with buckwheat but now it lay as being cut and broken on the ground

and another farce very nice a farmer on his land with his hay which was stacked on large piles he was taken up in the air and before he knew it was thrown in a dry ditch for as long as the gusts lasted

while the wind took the hay in its flight floating like plumes in the air when the farmer regained his calm having lost his senses he did not recognize his own land since all hay piles were gone

he thought: this is very spooky am I sleeping or dreaming and it doesn't look here as it just did I don't see hay on the land and there are no trees along the border 
en ginder mis ick oock een tooren

45

want in de veluw daer omtrent

bleef naeu een tooren over ent veel huysen sijn ter neer gedreeven

't *Hilversom* een weever wou noch sitten gaen op sijn getou om soo een uurtien noch te weeven

46 het onweer quam soo schielijck aen 'k heb het van mijn botter boer verstaen wins lant was daer omtrent geleegen dat 't huys hem woey los over 't hooft bleef op 't getou van dack berooft daer sitten in dien harden reegen

47 de post die na onweer doe van Arnhem quam na Uttrecht toe die hadde dit noch gaen verklaren dat t'onweer veel scha had gedaen en maer 'e'en tooren hadt sien staen van al die dorpen die daer waren

te ${ }^{*}$ wesep* daer gebeurde dit dat door de schoorsteen van een smit een keyselsteen quam nederdalen tot in de kamer op de vloer en maeckten daer een groot rumoer soo mijn de putter ginck verhalen

49 de smit die daer recht onder sadt die dacht wel wat geluyt is dat hij schrikte voor dat vreemd gerommel hij metter haest na boven toe vont daer een heete steen maer hoe die daer quam dacht hij weet den drommel

50 de schoorsteen naeu de steen was groot soo dat die oock ter nauwer noot tisschen de muren con passeren maer hadt ten weder sij gemaeckt een streepen in de muur gemaeckt dat meenich mens quam visenteeren

51 lach op de schoorsteen dan geen steen wat hem geuraeckt, de smit seyt neen and in the distance I also miss a tower

Because in the area of the Veluwe

hardly a tower was upright many houses were demolished in Hilversum a weaver wanted to sit at his weaving-loom to weave for an hour

the lightning came so very quickly I have heard this from my butter farmer whose land was in the vicinity that the house broke down over his head and he sat on the weaving-loom, robbed of his roof sitting in the pouring rain

the mailman which came after the thunder storm from Arnhem to Utrecht had to declare that the thunder storm had done much damage he had seen only one tower erect in all the villages on his journey

in Wezep happen this through the chimney of a black smith a large pebble came down into the room on the floor and made a large uproar as was told by my water-drawer

the black smith who was sitting right under it thought what noise is that he startled from the rumble and hurried upstairs where he found a hot stone but how it ever came there he didn't know

the chimney was narrow and the stone large so that it could hardly pass between the walls it made on both sides carves on the walls which many people came to look at

wasn't there a stone lying on the chimney which could explain this, the black smith said no 
geen steenen lach daer op in lange maer 't sij dan waer hij comt vandaen ' $\mathrm{k}$ sal hem in ijsere banden staen en voor 't huys aen de gevel hangen

van dier gelijck geen schrift men vint tot ${ }^{*}$ ouwerkerk* daer heeft de wint de tooren ook gaen nedervellen d' heer meijer daer woonachtich is verhaelden een geschiedenis wel waerdich om hier bij te stellen

een huysman met twee soonen 't saem in 't lant was met een boerepraem sijn uyt het water opgenoomen met praem en al hier wel op let over twee kampen lant geset een soon die isser afgekoomen

54 de andre of die overboort en soo in 't water sijn versmoort of door den slach waren geschonden daer af soo wist hij geen bescheyt alleen soo heeft hij dit geseijt hij hadt niet nader onder vonden ick gae hier noch al veel voorbij van schade die aen alle zij geschiet sijn die ick al laet blijven aen huijsen boomen tuijn en hof ick sou wel vinden so veel stof een boeck papier heel te beschrijven

de *diemermeer* kreeck oock sijn deel daer was de schade oock teveel voor ijder die dat moest betalen soo stel ick hier allenich maer 't huijs van karel van huffelaer soo hij mijn sellef ginck verhalen sijn hofstee onlangs weer hestelt de glasen stucken en in't velt lagen de pannen en de vorsten voort in de schuer een wonderding daer waren uit de soldering drij planken 't sessens uijt gebarsten no stone was lying there but where ever it came from I will hang it in iron straps and hang it on the face of the house

no equal is found in the books in Ouwerkerk has the wind destroyed the tower as well mister Meijer who lives there told a story worthy enough to tell here

a farmer with his two sons together was near his land on a farmer's pram they are taken out of the water and relocated with praam and all a distance of two lots one son survived

the other was swept overboard and must have drowned in the water or died due to the impact

he just did not know all what he said is that he never had experienced anything like it

I am ignoring quite a few cases of damage which happened all around to houses, trees, garden and courts it would be easy to find enough material to write a book

the Diemermeer got its share as well the damage was too extensive for anybody to pay as an example I tell about the house of Karel van Huffelaer as he told me himself

his farmstead was recently repaired the glass was broken and in the field were the tiles and ridges in the barn a wonder three boards broke away from the carpentry of the attic 
en maekte so een gadt in 't dack soo groot gelijck een volle sack nam sperren riet en latten meede en vlooch soo weder om daer deur nu denckt eens ijder heeft sijn keur of dit de wint of donder deede

noch was hij hier mee niet al vrij want eer het onweer was fobij soo reedt hij naer stee met sijn wagen maer eer hij noch quam aen de stadt soo heeft de donder hem te radt de wagen heel stucken geslagen

de menschen vielen in een plas daer bij geval juijst water was en moesten daer soo blijven leggen de schrick en vreese was heel groot 't geluck noch grooter in dees noot niemant wist van quetsuer te seggen

61 maer bleeven algesont van leen de paerden liepen naer de stadt heen 'k meen als ghij dat gaet overweegen dat ghij dat vatten sult veeleer dat andre huijsen in de meer oock dapper schae hebben gekreegen

rotman's tuin die aan d'amstel leijt ist loot van't dack venster gewayt een stuck meer als dri hondert ponden de spijkers ruckten 't hooft door 't loot is in het velt over de sloot vijf hondert voet van daer gevonden aen *d'overtoom* en daer omtrent sijn oock al veel huijsen geschent de tuijnen aen die wech geleegen hebben aen vruchten en gewas aen schoorsteen dacken en aen glas seer dapper veel schade gekreegen

veel menschen hadden groot verlies maer in de tuijn van Aux Brebies daer geschieden oock vreemde saecken and made a hole in the roof as large as a filled sack it took thatch and latches and flew right back again now everybody, think this over was it the wind or the thunder?

the ordeal was not over yet before the thunder storm had passed he rode with his wagon to the city but before he came there the thunder got to him and smashed the carriage to pieces

the people fell in a pool which happened to have some water and had to stay there lying because of tremendous fright and fear the fortune was larger than their distress because nobody was hurt

they were healthy of life and limbs the horses walked to the city I think that when you contemplate this you would easily understand that other houses in the Meer also got damaged quite extensively

In Rotman's garden which is on the bank of the Amstel river the lead used for the attic window was blown away a piece of more than threehunderd pounds the nails pulled their heads through the lead and in the field across the ditch it was found, five hunderd feet away

Near the Overtoom and in that area many houses were damaged as well the gardens which bordered the road have their fruits and crop damaged chimneys, roofs and glas were all heavily damaged

many people suffered great losses but in the garden of Aux Brebies strange things happened 
de schoorsteen van de hoohen brack en woeij volkoomen overt dack sonder de pannen eens te raecken

hij woeij gelijck een pluym daer heen men sach op 't dack noch puijn noch steen glijck of hij over was gevloogen sijn buerman's muur dick ende groot die woeij soo los over de sloot glijck meenich dat sach voor sijn oogen

Mattijs Verhagen was niet vrij quam met een vroumens aen sijn sij naer huys toe rijden met sijn wagen die van de wech af met gewelt soo Aux Brebies mijn heeft vertelt in't water worden neer geslagen

met waegen paerden en de rest maer 't viel noch uit op sijn best hoewel in groot perykel waren quamen daer noch behouden af doe sij in Aux Brebiesen hof noch raekten om wat te bedaren

veel hielden't voor den jongsten dach want men noeijt diergelijcken sach de mannen die te paerde saten die woeijen om met paerdt met al schout engelbrecht van soo een val can van 't geval met recht wel praten

de schuijten in dien smalle stroom tussen de stadt en *d'overtoom* sijn oock niet ongeschent gebleeven die sonder seijlen woeijen om en tuijmelden noch om en 't om dat kosten oock veel menschen 't leeven die sij omtrent van *slooten* brocht en met haer schuijt weer huijswaerts spoeden die wort gedreeven aen de kant met schuijt met al geset op't lant 't bleeck dat haer godt noch wou behouden

the highest chimney broke and was blown right over the roof without even touching the tiles

the thing blew like a feather away on the roof, no debris or stones were found like it flew right over it his neighbour's wall thick and large blew away over the ditch which was seen by many a men

Matthijs Verhagen was harmed as well he came riding with a woman side-by-side to his house with his wagon which was driven off the road by force as Aux Brebies has told me and landed in the water

with wagon, horses and the rest but it turned out for the better although they were in great distress they came off unscanted and got to the Aux Brebies house to calm down a bit

many held it for the youngest day because they haven't seen anything like it man riding the horses were blown down with their horses sheriff Engelbrecht has had such a fall and he tells you about the details

the boats in the narrow streams between the city and the Overtoom were not left undamaged as well those without sails were blown on their sides and tumbled over and over which costed many lives

a farmer's wife had sold her milk which she had brought from Slooten en with her boat she hurried home but it was driven to the bank and with boat and all she was put on land but her God wanted to salvage her 
71

$\mathrm{d}^{\prime *}$ haerlemse* vaert en daer omtrent

sijn oock al veel huijsen geschent veel menschen raekten oock in't lijden van twee vrinden stel ick de naem die ijder met een kar te saem met haer geschelschap quamen rijden

72 den 'e'en raekten sijn kar ontstelt recht eer de wint quam met gewelt van neck reedt met de vroulien heenen wort schielijck van sijn haet berooft creeg groote buijlen op het hooft al door de sware hagel steenen

73 tot hun geluck een huys niet veer 't hadt anders noch gehapert meer daer sij hun berchden voor de winden Draven verliet kar en paert raeckten wel dri mael in de vaert eer hij 't geselschap conde vinden

74 wagen en paerden hielt geen stant maer raeckten in de vaert van 't lant verschaeijde die in 't water raeckten en aen de kant hun hielden vast en lagen daer in sulken last tot dat de felle wint wat slaeckte een steeman deed mij dit verhael van't geen gebuert is den fiscael die quam van *haerlem* herwaers rijden die woeij tot twee mael met sijn paert van de wech af tot de vaert hij kost hem daer af niet vermijden

d' schae was on wondeerelijck twee en twintich saech moolens glijck ses koren moolens op stads wallen behalven die aen roe en heck of aen de kop of aen het deck beschadicht waren sijn gevallen

in tegen deel een huijsien staet als men de leijtse poort uytgaet soo naer de weetering toe gaende staet alleen aen de singel kant in the area of the Haarlem canal many houses were damaged many people suffered there as well I have the names of two friends both came riding in with their wagon accompagnied by female company

one of them had his wagon broken when the winds came with its force Van Neck rode away with his wife but he was robbed from his hat he got large bumps on his head by the heavy hail stones

they were lucky enough to reach a nearby house otherwise they would have been hurt even more and they could shelter for the winds Draven abandoned his carriage and horse got into in the canal thrice before he could be rejoin the couple.

Carriage and horses couldn't stand firm but landed in the canal several of those who were in the water held on tightly on the banks and were waiting in great distress untill the fierce winds slackened

a city-dweller told me the story of what happened to the tax inspector he came riding from Haarlem but was blown twice, with his horse, off the road into the canal He could not avoid that.

the damage was unbelievable twenty two saw mills along with six wheat mills on the city walls have fallen over, not counting those with damage to sail-arms, fences, or heads or decks.

in contrast a little house stands where one exits the Leydsepoort in the direction of the watercourse it stand alone on the banks of the moat 
met sout haest breecken met de hant is onbeschadicht blijven staende

78 dat groote heck seer vast geschoort tot slot van de haerlemmerpoort is met gewelt oock neer geslagen 't kruijs op de poort aen stucken brack van d' heijlge pee kreeg oock een krack veel grooter als het kon verdragen

want met het naeste ongeweer 'k quam oock dat kruys van booven neer 't begijnhofs kruijs is oock geweken 't kruijs op de westertoren hooch dien fellen wint oock needer booch 't ijser was taeij en wou niet breecken

80 dees wint quam hier soo metter vlucht gelijck een blicksem uyt de lucht 's avons wat voor de klock van acht uren met sulck een gruwelijck tempeest geen huijs waer ongeschent geweest hadt het maer een uur blijven dueren

81 in een quartier een korten tijt was meenich huijs sijn schoorsteen quijt en andre die noch bleeven staende al scheen hun dat soo wel geluckt daer sijn de kappen afgeruckt en maekten soo de daecken gaende

82 dat soo een huijs licht wort berooft van pannen can wel sijn gelooft door felle wint dat is geen wonder maer dat het loot een swaren last wel gesoldeert gespijkert vast wort afgeruckt daer speelt wat onder een loodgieter vertelde mij dat van't huijs der dijaconij was af meer als twee duijsent ponden maer was gevallen 't haerder baet soo op de plaes als op de straet daer sij het hebben weer gevonden you could even break it with bare hands but it was left undamaged!

that huge gate, very tightly attached blocking the Haarlemmerpoort is beaten down with great force the cross on top of the gate is broken in pieces the holy Peter received a crack as well much larger than it could take

because with that terrible thunder that cross came down the Begijnhofs' cross came down as well the cross of the Westertoren high was blown down by the furious winds the iron was sturdy and would not break

these winds came with such speed like a thunderbolt from the sky in the evening, just before 8 o'clock with this atrocious tempest no house would have been undamaged if it would have lasted an hour

in a quarter of an hour - a short time many houses lost its chimney and of those who had it still standing eventhough they managed to do that they had their roofs ripped off which were then blown away

that a house is quickly robbed of its tiles is not too hard to believe because of these furious winds but that the lead, with all its weight firmly brazed and nailed was torn away also, that's a miracle

a plummer told me that the house of the poor-relief board lost lead in excess of two thousand pounds which fell down to their distress both on the street and the court where they found it again but on the exchange things were too rough 
woey wel vier duysent ponden af

't waren seven en twintich stucken

in een kaes winkel daer omtrent

was een stuck in 't cosijn belent men kon't niet netter daer in drucken

een groot gedeelt viel op de straet oock veel in 't water dat was quaet dat kon men so licht niet weer krijgen maer datter noch gebuerde meer aent huijs van trip een borger heer dat moet ick hier oock niet verswijgen

op dat huys was een plat seer groot wel vast gedekt met wichtich loot dat loot dat soo vast was geleegen eenige duysent ponden swaer was opgerolt al in malkaer geen menschen hadden 't soo gekregen

veel gevels daer het schoon ciraet van boven neer lach op de straet van schoone potten en kanteelen mijn kosijn Koog deed een verhael daer Leijen uijt hangt op de Wael dat wonder moet ick u mee deelen

de leeu op 't huijs stont wonder vast met twee ankers is door de last der fellen wint omveer gesmeen een out plat boven op het dack half vergaen was out en swack daer heeft met van geen scha geweete

de huysen waren soo ontbloot 't gebrek aan pannen was soo groot dat nooijt gesien was van ons leven twee stuyvers stuck dat can noch gaen moet worden oock soo ' $k$ heb verstaen vijf ses stuyvers voor 't stuck gegeven seylen en matten was goet deck de metsers waren groot gebreck men kost geen timmerlien bekoomen 't was bet als twee maenden daer naer eer alles weder raeckten klaer some four thousand pounds of lead blew away it were twenty-seven pieces in a chees store in the area a piece had landed in a window-frame you couldn't put it there more neatly

a large part fell on the streets as well as in the water which was too bad because it was very hard to recover but even more things happened in the house of Trip, a citizen gentleman things I should not hold for myself

on that house was a very large flat roof well-laid with weighty lead that lead was put down so firmly and weighted a few thousand pounds was rolled-up to itself no man could have done that

many facades which decorated the houses fell down on the streets, with their lovely gables and battlements My cousin Koog told me a story ?

that miracle I must tell you

the lion on the house was firmly attached with two braces but through the force of the furious winds it turned over but a wooden flat on top of a roof partly rotten and weak in structure was not damaged at all

the houses were so naked the shortage of tiles was so great that we had never seen before in our lives two pennies each is reasonable but the price increased, I have heard, to five or six pennies each

canvas and mats was fine coverage the bricklayers were in high demand one couldn't get a carpenter you were lucky if two months after everything was repaired 
dat heb ick selve best vernoomen

91 Dit was wel voor schoorsteen en dack maer glas en glaes makers gebrack ons noch veel meer want daer de winden dien swaren hegelsteenen teegendreef niet een glas in't geheel en bleef lantaren daecken heel veslinden

't Gae kerken, huijsen al verbij 't stadthuijs alleen aen de suijt sij een men dat weer met glas verhulden een glasmaker die seijt mijn dat dat hij die schae wel hadt geschadt al meerder als twee duijsent gulden want vielen sulke steenen swaer als kivistayeren bijnaer di door de glasen quamen slingeren men vont doen steenen in het velt verschaeijden hebben 't mijn vertelt soo groot als twee litten van vingeren

94 den regen was ook over groot glijck of het haest met emmers goot soo quam het langs de straten stroomen schipper loos meendt met een wip noch wel te raecken in sijn schip doen hij de buij so sach aen koomen

$95 \quad$ Hij quam soo veer dat hij noch pas op de buyck slooter steijger was daer wort hij schilijck soo benepen dat hij ten eersten viel om veer hadt noch gewoeijt van booven neer hadt hij niet an de kant gegrepen.

96 veel boomen heb ick voor geseijt aen stucken of om veer gewaeijt en mee nichten oock neer geboogen die weer gerecht sijn met gewelt met stutten schooren rechtgestelt op dat die weer vast groeijen moogen that is what I heard

that may have been fine for chimney and roof but glas and glass-makers were even thinner spread, since the winds drove all those heavy hail stones and not one window was spared nor any skylight.

Churches and houses all hit, the south side of the city hall was to be fitted with new windows a glazier told me that he had estimated the damage in excess of two thousand guilders

such large stones have fell almost like lapwing's eggs which came flying through the windows stones were found in the field, several have told me, as large as two phalanges

the rain was overwhelming as well like buckets were emptied it came streaming down the streets boatman Loos thought he could get to his boat in a jiffy when he saw the squall coming

he made it as far as the Buiksloot pier he got very frightened that he first fell to the ground he must have been blown away had he not grapped hold to the bank

I've heard from about many trees blown to pieces or overturned and those that only bended in the wind have been erected with force with supports and props so that can grow again

a heavy tree out of the soil which stood on the New Market 
dicker dan men omvamen konden is niet alleen geplotst terneer maer hondert tachtig voeten veer al van sijn aeijgen plaes gevonden

mijn susters plaesduer, die doenpas geslooten en gegrendelt was stont op de plaes heel sonder schaeden naer dat het onweer was gestaeckt maer hoe dat hij daer was geraeckt was niemant die dat konde raden

Tot josep duijs is mijn vertelt een vles met roos eeck was gestelt om door de son te disteleeren wel twintich voeten hoogh of bet was neder op de plaets geset sonder de vles in't minst te deren

100

de weuw Blaeupot bij't Prinsen hof quam oock daer sonder scha niet af die sou beginnen wat te eeten en onder een lantaren sat een plaets daer men gemeenelijck at worden de glasen ingesmeeten

101 een koeck daer op tafel stont de korst was weg men die niet vont het scheen oft daer begon te spooken de steenen borden al om veer een bier glas oock van boven neer niet een en was er afgebrooken

een vlesien oock watter dat stont al in een schootel uyt de mont van Jasper Lemmers dit geschreven op tafel binnen in een huys de schootel die lach heel in gruijs en't vlesien dat was heel gebleeven

103 'd heer Mollo die was met sijn bruijt gerede met sijn cheese uit daer was geen vrees voor harde winden die hij weer 's avons 't huijs waert bracht en quam tot op de heeregracht recht voor de duer van sijn beminde thicker than one could embrace not only fell to the ground but was moved from its place some 180 feet

the front door of my sisters' house which was locked and bolted stood on the square without any scratch after the thunderstorm had ceased but how it got there nobody could tell

Joseph Duijs told me a bottle with wine was set to have it distilled by the sun as much as twenty feet it was lifted and put down on its place again without damaging the bottle the least

the widow Bluepot near the Prinsenhof did not get through the ordeal undamaged she was starting her supper and sat under a lantern a place where people often eat the glas windows were smashed

a cake which was on the table the crust was gone, nowhere to be found it appeared as if it was haunted the clay plates fell down a glass of beer as well not one was broken

a jug filled with water on a saucer, I heard this from the mouth of Jasper Lemmers on the table in a house the saucer was in pieces but the jar was still in tact.

Mister Mollo was with his bride riding with his gig [two-wheeled chaise] he did not fear the strong winds when he brought her home in the evening he came up to the Heerengracht right in front of the door of his beloved 
104 terwijl de kar noch stont voor't huus soo quam de wint met fel gedruijs een donder die seer schrickelijck brulde en smeet twee boomen cort om veer d'een voor de d'ander achten neer dat soo de heele straet vervulde

105 daer stont de wagen met het paert ten con noch voor noch achter waert maer was beslooten met tween boomen met most een vlot schuijt brengen aen daer men de wagen op de gaen want con anders van daer niet koomen

106 dit was ellendich ouer al van al dat over groot getal der scheepen voort stee aen de paele hun touwen braecken door de kracht soo wasser maer ses ofte acht of raeckten driftich altemaele

anker noch tou quam niet te stae den een deed d'ander groote schae daer ginhen vijf of ses te gronde een boeijen rijckelijck gelaen men meende dat hij was vergaen is in de gout see weer gevonde

108 noch heb ick nader hant verstaen mijn sechsman is Rosier de Haen hoe dat de scheepen die daer lagen soo voor sijn duer en langs de kant naer Vranckrijck en naer Engelant die waren oock niet vrij van schaede

dien fellen wint soo onverwacht brack al hun tou door sijn kracht en maekten soo de scheepen gaende maer 't scheen een wonderlijck geval drie leege vaeten op de wal die bleeven onbeweechlijck staende

noch wonderlijcker was het dat een vroumens worden opgevat los van de wech omhooch gedreven while the carriage was standing before the house the winds came with angry howls a thunder which roared violently and overturned two trees one in front and one at the rear so that the entire street was blocked

there was the horse and carriage it could not move one way or the other since it was blocked by two trees a flat barge was needed to move the carriage otherwise it was not possible

this was the most horrible of all the large number of ships which were tied to the quay-wall their ropes broke because of the winds only six or eight were spared the rest drifted away

anchor nor mooring ropes were strong enough one did great damage to the other five or six went to the bottom a boat fully loaded which was thought to have perished was retrieved in the Gouwzee

afterwards I understood

my spokesman is Rosier de Haan

how that the ships lying there

which were supposed to sail

to France or England

were not free of damage either

the fierce winds so unexpected broke all their mooring ropes by its force and made the ships to drift away but it seemed a miraculous case that three empty barrels on the quay were not moved an inch

even more miraculous was that a woman was lifted in the air away from the road up in the air 
de wint die voert haer met gewelt over de sloot tot op het velt is in een boom hangen gebleeven

111 wie hoorden oijt van diergelijck tussen de beemster en quadijck is dit geschiet soo men mij verhaelde d' heer Colve dien ick daer voor hou dat hij niet licht iets seggen sou dat eenichsins de waerheijt faelde

112 die noch meer wonder weeten wil een meelmoolen is van de spil los opgetilt voorwaer een groot wonder wort om gekeert en soo heel net weer op de werf neergeset stont wel perfeckt het bovenste onder

113 'k heb het van Pieter Koog gehoort 't was buijten de Weteringspoort de eerste moolen al daer staende daer hij het selver hadt gesien en neffens hem wel duysen lien al om het wonder dat waer gaende

114 't was wonder hier soo dicht bij dat *haerlem* bleef daer af vrij met al de boomen en de tuijnen tot *alleckmaer* en daar ontrent was oock noch boom noch huijs geschent en dat soo verder naar *huijsduijne*

115 *sandam* dat kreech oock iet of wat maer raeckten maer een moolen plat en't *oossaen* daer soo bij geleegen daer sijn de huijsen meesten deen beschadigt of gevallen heel seer weijnich die geen schade kreegen

116 te *bijcksloot* vind ick oock al stof want aen Tomas Tobijas hof een speel schuijt lach om mee te vaaren wort met gewelt oock los geruckt 't een ent in 't hoender hock gedruckt soo hij mijn self quam verklaeren the winds drove her with force across the ditch into the field and landed in a tree

we heared of this event between the Beemster en Kwadijk it happened I was told by mister Colve who I trust not to say anything lightly which is besides the truth

he who wants to hear of more miracles a grain mill is lifted from its post surely a great miracle and was turned around and neatly set down on the wharf but perfectly upside down

I have heard from Pieter Hoog it was just outside the Weteringspoort the first mill that was standing there he had seen it himself all the miracles that happened made his head spin

it was a miracle that so close by Haarlem was spared with all its trees and gardens up till Alkmaar and whereabouts trees nor houses were damaged which continued up to Huisduinen

Zaandam got a little a wind mill was overturned and the Oostzaan, very close by, most of the houses there were damaged or destroyed very few had no damage at all

in Buiksloot there are things to tell as well because in the household of Tomas Tobijas a toy boat was lying there to sail with it was jerked loose with great force and pushed in the chicken-house which he himself testified to me 
117

maer 't alder wonderlijckste van al dat ick nu hier verhaelen sal dat mijn van Ommeren vertelde daer af wees hij de plaets oock aen 't was tussen 't *hallef* en *ossaen* dat hij oockk in geen twijfel stelde

118 hoe dat een vrou lach in de kraem van tween kinderen die te saem voor uijt de wieg sijn opgenomen het vier eerst uijt de wieg de kolck geruckt de kinders daer weer in gedruckt sijn noch gesont daer afgekoomen

119 noch heeft dien docktoor dat vertelt dat bij *ilpendam* in het velt twee huijslien quaemen aengevaren dient onweer oock heeft aen gerant en waeijde uit de schuyt op 't lant onbeschadicht gesmeeten waren

de schuijt die vlooch soo het wel scheen ouer verschaeijde ackers heen daer hem de donder seer most drucken want doen het onweer was gedaen dat men weer naer de schuijt sou gaen doen vont men hem in duijsent stucken.

te *ilpendam* een boere praem lach in de gront heel onbequaem en hadder wel een jaer geleegen verschaeijden hebben 't mij vertelt wort op het drooge lant gestelt dat diende hier oock niet versweegen

ons buerman Vries heeft oock verstaen van albert dirksen van oossaen dat daer een schuytien lach gebonden al met sijn seyltie toegedeckt de schuijt was wech is so perfect al tot * wessanen* weer gevonden

123 den proocureur van sterrevelt heeft mijn oock dier gelijck vertelt datter een schuijt is opgenomen met twee kinderen tot *bijcksloot* but the most miraculous of all that I will tell here now is what Van Ommeren told me he even pointed the exact place to me it was between Halfweg and Oostzaan he was very certain about it

it's about a woman who gave birth to two childeren who were taken up together from the cradle ?? and put the childeren back in the cradle they survived in good health

the doctor told me as well that near Ilpendam in the field two farmers came sailing in the thunderstorm hit them too and blew them from their boat on the land and threw them down unharmed

the boat flew as if it were across several fields the thunder must have hit it hard because when the storm had passed and the boat was found it was in a thousand pieces

In Ilpendam a farmer's pram was lying in the grounds it had been lying there for a year several have told me this it was put on dry land which need to be said here also

out neighbour Vries heard from Albert Dirksen from Oostzaan that a little boat was there covered with his sail the boat was gone and it found in perfect order near Westzaan

the solicitor of Sterrevelt told me of a similar tale that a little boat was taken up with two kids near Buijcksloot 
die worden baij gevonden doot

tot *purmerent* ist weer becomen

124

een kruijt molen bij *monkendam*

die Mewels en de Schot toe quam

so mijn d' heer krooch heeft gaen verhaelen

drie steenen lagen in de gront

ses loopers gingen daer in't ront

glijck men op die wijs 't kruijt moet malen

125

die ses loopers die steenen swaer

sijn opgenomen met malkaer

nooyt hoorde imant sulke daden

stijlen en spillen alles net

neffens de leggers neergeset

sonder de steenen te beschaden

126 noch meerder wonder hier bij komt

die swaere spillen omgecromt

die bleeuen in de steenen steken

die most men laugh saem vijlen af

want men kon sulke ijsers grof

toch met gewelt daer niet uit breken

127

te ${ }^{*}$ quadijck* ginck het oock hart aen

daer bleeven naeu drij huijsen staen

volkoomen daer niet aen en schorten

't getal was wel twee hondert groot

van dack en wanden heel ontbloot

verschaeijden die gans neder storten

128

te beets oosthuijsen aen die kant

en overt heele water lant

al waer die wint sijn rolle speelde waren de huijsen meest onstelt

beschadicht of plat neergevelt

seer weijnich die niet mee en deelde

129 oock in de stadt van *purmerent* sijn oock al veel huijsen geschent de tooren viel oock neer ter aerden de *beemster* die kreech oock sijn deel daer was de schade oock seer veel aen huijsen boomen en bogaerden and were found dead

somewhere near Purmerend

a powder mill near Monnikendam

which belonged to Mewels and de Schot

so has mister Krooch told me

three millstones were lying in the ground

six edge runners were used there

like what one does to mill the powder

the six edge runners the heavy stones were taken up in the air

nobody has ever heard of such deeds

axes and spindles, everything neatly

laid down next to the bed-stone

without damaging the stones

even more wonderous is this

the heavy axes, unbended,

remained sticking out of the stones

they had to be filed from the stones

such thick iron was

impossible to be removed by force

in Kwadijk much mischief was raised

hardly three houses were left standing

of those that were damaged

the number was two hunderd

robbed of roofs or walls

several were destroyed completely

In Beets Oosthuysen on that side

over the entire water land

where the winds played its role

the houses were damaged the most

injured or completely destroyed

very few were got away

also in the city Purmerend

many houses were damaged

the tower fell to the earth

the Beemster got his part also

the damage was extensive there as well

to houses, trees en orchards

complete rows of trees 
geschuert, geclooft al van malkaer gebrooken en als gewrongen of oock ontwortelt uyt de gront soo dat het daer nu deerlijck stont men kan 't uyt spreeken met geen tongen

op *wieringe* wast sogestelt een vrou heeft hier dat self vertelt haer solder wel geploecht gedreeven daer is dit wonder ook gebeurt een planck ten halven uytgeschuert en was die planck noch heel gebleeven

132 de grootste kerck daer in dat lant die plotste neer met dack en want de tooren most daer oock voor strijken de sarken van de graven af de dooden bij kans bloot in 't graf waer hoort men oijt van dier gelijcken

133 de moolens door dit swaer onweer heschadicht of heel plat ter neer soo dat se niet en konden malen waren gedwongen door den noot dat men het meel en oock het broot met schuijten most van verre haelen

134 In't Texsel was een groot effent de meeste schae was aent oost ent daer veel scheepen aent ankers lagen die van hare ankers sijn gespilt en doe het onweer was gestilt men daer bij naest geen scheepen lagen

maer saten hier en daer om hoogh de felle wint dreef haer op droogh behalven die daer sijn gesonken men mist er net vijf in't getal die waren wech met goet en al en al die menschen sijn verdroncken

136 de schade was ongemeeten groot over de heele gansche vloot van ankers kabels en van touwen veel masten glijck als afgedraeijt de seijlen los daer heen gewaeyt were torn, cleaved and broken in two and twisted or uprooted from the soils on could not speak of the sight of it all

on Wieringen it was like this a woman has told me herself het attic, well made where this miracle happened a board was ripped away but the board was still in tact

the largest church there in the land collapsed with roof and walls the tower was torn down as well the tombstones were removed from the graves the dead were nearly naked in their graves have you ever heard of anything such like?

the windmills damaged by this heavy thunderstorm or lying flat on the ground could not mill anymore. people were forced because of this to get flour and also bread by ship from far

on Texel was a large event most of the damage was at the eastern edge where the ships were anchored they broke adrift and when the thunder had passed hardly any ship was lying there anymore

they were here-and-there diven on dry grounds by the fierce winds except those which sunk some five in total they were gone with cargo and goods and all the sailors drowned

the damage was beyond description for the entire fleet anchors lost and ropes and cables broken many masts snapped and twisted the sails blown away 
geluckich die sijn schip mocht houwen

137 Hoe 't nu op 't aeijlant heeft gegaen daer af en heb ick niet verstaen maer dit kan ick daer wel af gissen daert alles is ontramponeert al waer die buij is gepasseert dat het op tessel niet con missen

138 dees felle wint of wel orkaen die is doen see waert in gegaen daer hoord ick van geen schae gewagen maer sijnder scheepen mee geplacht of om gewaeijt te gront geijacht die sullen 't ons niet komen klagen happy the man that could keep his ship

how things fared on the island

I have not heard

but I think I can guess

that everything is destroyed

where the thunderstorm passed

it could not have missed Texel

this furious wind or hurricane

then moved seawards

I haven't heard of any damage done there but if there were ships who noticed

then they will be driven to the grounds by the winds and won't come to us to complain 